\title{
Exploring how student motivation relates to acceptance and participation in MOOCs
}

\section{Esteban Romero-Frías ${ }^{1 *}$,José-Luis Arquero ${ }^{2}$ and Salvador del Barrio-García ${ }^{3}$}

${ }^{1}$ Medialab UGR, University of Granada, Gran Via, 48, 4. 18071 Granada (Spain) Orcid: 0000-0003-2205-3560

(España) $/ /{ }^{2}$ Departamento de Contabilidad y Economía Financiera, Universidad de Sevilla, Av. Ramón y Cajal, 1. 41018 Sevilla (Spain) Orcid 0000-0002-7086-8812

(España) $/ /{ }^{3}$ Department of Marketing and Market Research, University of Granada, Campus de Cartuja s/n. 18071 Granada (Spain) Orcid: 0000-0002-6144-0240

${ }^{1}$ erf@ugr.es//2arquero@us.es//32dbarrio@ugr.es

Reference: Romero-Frías, E., Arquero, J.L., \& del Barrio-García, S. (2020). Exploring how student motivation relates to acceptance and participation in MOOCs. Interactive Learning Environments. http://dx.doi.org/10.1080/10494820.2020.1799020

Dr. Esteban Romero-Frías is an Associate Professor in the Department of Financial Economics and Accounting at the University of Granada and Director of Medialab UGR - Research Laboratory for Digital Culture and Society, within the Vice-Rectorate for Research and Knowledge Transfer of the University of Granada. He has published research works in prestigious journals in the fields of Education (i.e. Comunicar) and Information Science (i.e. Scientometrics, JASIST, JIS).

Dr. Jose Luis Arquero is a Senior Lecturer in Accounting at the University of Seville (Spain). He has published extensively on Accounting Education in international journals and is currently the editor of the Spanish Journal of Accounting, Finance and Management Education.

Dr. Salvador del Barrio-García is a Full Professor in the Department of Marketing and Market Research at the University of Granada. His research focuses on areas such as Integrated Marketing Communication (IMC), Online Consumer Behavior, and Cross-cultural Marketing. He has published several peer-reviewed papers in prestigious journals such as the Journal of Interactive Marketing, the Journal of Business Research, and the European Journal of Marketing, among others.

\section{Declaration of Conflicting Interests}

The authors declare no potential conflicts of interest with respect to the research, authorship, and/or publication of this article.

\section{Acknowlegments}

We gratefully acknowledge the help of the Resource Production Centre for the Digital University (CEPRUD) of the University of Granada for providing access to the MOOC database. 


\title{
Exploring how student motivation relates to acceptance and participation in MOOCs
}

\author{
In recent years, MOOCs have become firmly established as valid e-learning \\ environments and, as such, have been developed by many universities using different \\ types of platform. Given the voluntary nature of MOOC enrolment, motivation is \\ crucial to our understanding of why students register for and complete these courses. \\ The present study explores the motivations that characterize MOOC participants and \\ how they relate to technology acceptance variables (data collected via questionnaires) \\ and participation variables (observational data collected via the platform). Our results \\ indicate that students show exceptionally high levels of intrinsic motivation. However, \\ extrinsic motivation also plays a relevant role, suggesting that the two are not mutually \\ exclusive. Although only intrinsic motivation appears to be systematically associated \\ with differences in technology acceptance, both are associated with differences in \\ participation, but in contrasting ways. Our results provide insights that will enable us to \\ improve MOOC design in order to enhance participant satisfaction, particularly when \\ different sources of motivation are involved. Future research based on the modeling of \\ technology acceptance and participation will also benefit from this study.
}

Keywords: motivation; participation; technology acceptance; self-determination theory; MOOC

\section{Introduction}

Massive Open Online Courses, also known as MOOCs, are open, non-formal learning opportunities that can attract hundreds or even thousands of participants with a wide range of motivations for starting and completing the experience. Generally, MOOCs are free-access, non-cost, and voluntary learning experiences in which students are usually highly motivated at the outset (Barba, Kennedy, \& Ainley, 2016). Given that relatively few initially-registered participants finish these courses (e.g., Clow, 2013; MOOCs@Edinburgh Group, 2013), research has usually focused on the links between motivation and attrition (Deshpande \& Chukhlomin, 2017). The limited social interaction of an online environment raises questions about student engagement and motivation in MOOCs (Xiong et al., 2015; Martin, Kelly \& Terry, 2018) because the "massive" component makes interaction more complex. Lei (2010) stressed that lack of motivation is directly related to learners deciding to stop learning. In this context, Yang (2014) suggested that the relationship between motivation and participation becomes stronger and more significant as classes progress.

In recent years a growing number of studies have explored the relations between motivation and other variables traditionally linked to technology acceptance and participation in MOOCs. Abdullatif and Velázquez-Iturbide (2019) analyzed the relationships between the intention to 
continue using MOOCS, internal and external motivation to use them, and personality traits. They found that external motivations have negative but insignificant impacts on continuance intention whereas internal motivations have a significant positive effect. Alraimi, Zo and Ciganek (2015) used variables such as intrinsic motivation (satisfaction and perceived enjoyment), extrinsic motivation (perceived usefulness), and MOOC continuance intention and found statistically significant — but slight - positive effects. Using a less complex model, Joo, So and Kim (2018) found satisfaction and perceived usefulness had a stronger positive effect on continuance. $\mathrm{Wu}$ and Cheng (2017) studied continuance intention by using a unified model integrating the technology acceptance (TAM) and task fit technology (TTF) models, and social motivation. They found that adding these to the model provided more accurate results. Tsai et al. (2018) also showed that user experience significantly influenced continuance intention. Our study contributes to this research by adding a "loyalty to the institution" variable and expanding the methodology in order to combine survey data and platform log data drawn from a considerably higher number of participants than the aforementioned studies.

Furthermore, we can report a substantially higher completion rate than the earlier analyses. More than $60 \%$ of registered participants completed the course under study, as opposed to dropout rates in the order of $86 \%$ (Gomez-Zermeno and Aleman 2016) or $90 \%$ (Hew and Cheung 2014). Therefore, in line with Brooker, Corrin, De Barba, Lodge and Kennedy (2018), we believe we need to understand how different types and levels of motivation relate to those variables that guarantee students a successful learning experience. Recent studies have explored the implementation of motivational strategies in MOOCs. For example, Li and Moore (2018) and Uçar and Kumtepe (2018) have addressed the issue by using Keller's ARCS-V motivational design model.

The benefits of analyzing motivations in e-learning, particularly, in MOOCs, have been widely recognized by the research community (Bekele, 2010). Gašević, Kovanović, Joksimović and Siemens (2014) identified motivation as one of the five main MOOC-related research themes of the future. Many authors (DeBoer et al.,2013; Gašević et al., 2014; Terras \& Ramsay, 2015; Barba et al., 2016; Riel \& Lawless, 2017; Lee, Watson, \& Watson, 2019) have stressed the need for further analysis of learner motivation, self-regulated learning strategies, attitudes, and behavior, in order to better understand the MOOC experience. Hence, more detailed analysis of motivation and how it influences participant interaction and the perception of MOOCs as learning tools is of major interest. However, to date, the vast majority of studies has solely been based on participant perceptions and has not included objective data about student behavior on the platform. Based on empirical data (44 out of 362 papers analyzed), Bozkurt et al. (2017) reported that the methodology most commonly used in MOOC research is the survey. They found only 22 papers based on data mining and analytics, and only 5 that used log analysisthe approach we adopt. Therefore, the present paper contributes to the scarce literature on this topic by combining both sources of information to obtain a deeper understanding of motivation in MOOCs.

\section{Literature review}

\subsection{MOOC overview}

MOOCs emerged in 2008 as an online, distributed and accessible educational experiment led by George Siemens and Stephen Downes and aimed at implementing their ideas of connectivism (Downes, 2005; Siemens, 2005), a theory that explains how different digital technologies create learning opportunities through information sharing. Courses described as MOOCs usually share features like open resource production, access to a variety of learning 
resources, the ability to interact with peers, and sharing and co-creating knowledge (De Freitas, Morgan, y Gibson, 2015; Fournier y Kop, 2015; Kop, 2011). Typically, a distinction is made between cMOOCs (based on connectivism) and xMOOCs (based on social behavior theories and constructivism) (Ebben \& Murphy, 2014). Generally, xMOOCs take place on big platforms that include a commercial component (e.g. Coursera, Udacity, edX) which aims to take advantage of the massive nature of the courses and access personal data through registration procedures.

MOOCs have become fashionable in education, research, and the media (Bali, 2014; Bulfin, Pangrazio, y Selwyn, 2014). This has given rise to many reflections about their nature and several taxonomies have been proposed: e.g. Liyanagunawardena et al. (2019). Bozkurt, Akgün-Özbek and Zawacki-Richter (2017) analyzed over 350 empirical studies to identify and map trends and patterns in research on MOOCs using the cMOOC and XMOOC distinction, and hybrid approaches. They also noted that, over the last ten years, the MOOC phenomenon has been called everything from a disruptive innovation to an educational buzzword. We agree that in recent years we have gone from highly inflated expectations to stabilization and maturity; MOOCs are now presented as alternative, open forms of training, of particular relevance given the new conditions generated by the covid-19 crisis.

\subsection{Motivation and Self-Determination Theory}

As Kim, Park, Cozart and Lee (2015) note, motivation is critical in learning, including elearning. If motives lead to behavior (Assael, 1984), once activated they become true motivations (Kagan, 1972). Firat, Kilinç and Yüzer (2018) stress that motivation is one "of the most important factors affecting the speed, intensity, direction, and persistence of human behavior" (p. 63). Therefore, motivations direct, arouse, and maintain goal-oriented behavior (Bandura, 2006) and, in a learning context, they support the participant's predisposition to learn (Nawaz, Aminz, \& Tatla, 2015; Schmidt, 2014) and determine how they maintain interest in any given learning activity. As Arquero, Fernández-Polvillo, Hassall and Joyce (2015) stress, the links between motivation and educational outcomes - such as interest, persistence or performance (Deci \& Ryan, 1985) - justify the importance accorded to motivation and to its assessment in educational settings (Cokley, 2000).

In the present study, self-determination theory (SDT) (Deci \& Ryan, 1980, 1985) increasingly of interest in the MOOC literature (Khan et al, 2017; Martin et al, 2018)-has shaped our view of academic motivation. In SDT, motivation can be intrinsically or extrinsically oriented (Cokley, 2000; Vallerand et al., 1992) and students present motivations along a continuum ranging from lack of control to self-determination: from no motivation at all (amotivation), to externally oriented motivation (extrinsic), to internally oriented motivation (intrinsic).

Deci and Ryan (1985: 1004) define intrinsic motivation (IM) as "doing an activity for itself, and the pleasure and satisfaction derived from participation. An example of IM is the student that goes to classes because he or she finds it interesting and satisfying to learn more about certain subjects". High IM levels are related to greater persistence, better ability to cope with failure, more positive self-perception, and higher quality task engagement (Tu \& McIsaac, 2002). Although Ryan and Deci (2000) presented IM as a one-dimensional construct, Vallerand et al. (1992) proposed three types of IM (pp. 1005-1006): (a) IM-to know, which is more closely related to educational settings and in which the source of motivation is the satisfaction experienced while learning or understanding new things; (b) IM to accomplish things, linked to challenges and becoming involved in activities "for the pleasure and satisfaction experienced 
when one attempts to accomplish or create something"; (c) IM to experience stimulation, which is linked to sensory pleasure or aesthetic experiences.

In contrast, extrinsic motivation (EM) is defined as the "performance of an activity in order to attain some separable outcome" (Ryan \& Deci, 2000, p. 71). In EM, the activity is not the end in itself, but a means to obtain a different objective. Ryan and Deci (2000) and Vallerand et al. (1992) define different levels of EM. The least self-determined EM behavior is external regulation. This occurs in activities that are performed to satisfy an external demand, obtain a reward, or avoid punishment (e.g. "I did the course to obtain credits"). Introjected regulation EM is a more controlled form of EM appearing when individuals begin to internalize the causes of their actions, even though the source of motivation is mainly external (e.g. "I did the course to prove to myself that I am capable of completing it"). Finally, identification, which is the most regulated form of EM. It reflects the conscious attachment of value to an external motive that is accepted as personally important and has been internalized (e.g. "Because this will help me make a better choice regarding my career orientation").

Previous studies (Alraimi, Zo, \& Ciganek, 2015; Zheng, Rosson, Shih, \& Carroll, 2015; Milligan \& Littlejohn, 2017; Watted \& Barak, 2018; Wu \& Chen, 2017) have revealed that learner motivation to participate in MOOCs is a combination of internal factors (e.g. personal interests, curiosity) and external factors (credit awarding, development of job competencies and the reputation of the institution that offers the MOOC). Given the characteristics of our course context and of the students who responded, we considered that IM-to know and extrinsic regulation EM were the most relevant measures of motivation. As participation in MOOCs is voluntary, amotivation is usually considered irrelevant. Moreover, all our respondents completed the MOOC.

\subsection{Acceptance and participation in MOOCs}

Participant acceptance of the use of technology in education is essential to the success of that technology. Technology acceptance, how a technology emerges and is adopted (Joo, So, \& Kim, 2018), has been studied using various theories and models: the Technology Acceptance Model (TAM) (Davis, Bagozzi,\& Warshaw, 1989) is one of the most widely-used in education thanks to its predictive validity (Sanchez-Franco, 2010; Hsu, Chen, \& Ting, 2018). Its success has led to adaptations such as UTAUT (Venkatesh, Morris, Davis, \& Davis, 2003), WAM (Castañeda, Muñoz-Leiva, \& Luque, 2007), or L2.0AM (del Barrio-García, Arquero, \& Romero-Frías, 2015), among others.

The TAM provides accurate estimations of IT usage by connecting behaviors, attitudes and beliefs (Perceived Usefulness [PU], and Perceived Ease of Use [PEU]) that are consistent in time, target, and context with using the system (Wixom \& Todd, 2005). Following the seminal work by Davis et al. (1989), PU and PEU have been considered, with broad-ranging empirical support, as fundamental determinants of user acceptance. The former measures the extent to which a potential user perceives a given technology as offering better value over alternative methods of performing the same task (Liu, Liao, \& Pratt, 2009); the latter measures the degree to which a potential user conceives the use of a given technology to be relatively effort-free (Davis et al., 1989).

Fishbein and Ajzen (1974) noted that, although there are different definitions of attitude, the consensus view is that a predisposition to respond favorably or unfavorably is essential to the concept. Along similar lines, Ajzen (1988) conceptualized attitude as a predisposition to respond favorably or unfavorably to an object, person, event, institution, or other discriminable aspect of the individual's world, highlighting the idea of evaluation. Using this 
conceptualization, Davis (1993) developed the Attitude Towards Using (ATU) scale to evaluate the users' attitudinal response to a system.

Loyalty (LOY) is a widely-used, multidimensional construct (Han \& Ryu, 2009) — particularly common in management studies - related to feelings of attachment to, or affection for products or services. It has a decisive influence on repeated use (or purchase) and on further recommendations to friends and other potential users. Student loyalty has been examined in higher education in relation to institutions as a whole (e.g., Hennig-Thurau, Langer, \& Hansen, 2001; Helgesen \& Nesset, 2007) and to educational experience with technology (Arquero, del Barrio-García, \& Romero-Frías, 2017). In this second sense, the strong link between attitudes, as a relevant antecedent, and loyalty has been highlighted (e.g., Han \& Ryu, 2009; Arquero, et al., 2017).

Finally, in parallel with technology acceptance, the role of user satisfaction (SAT) has been studied (Melone 1990; Del Barrio-García et al., 2015). In our context, SAT is a psychological state resulting from combining user expectations and feelings when using technology (Lorenzo, Oblinger, \& Dziuban, 2007). In an educational context, SAT can be defined as the student's overall positive assessment of the learning experience (Keller, 1983). A significant relationship also exists between learning satisfaction and the intention to use e-learning (Roca, Chiub, \& Martínez, 2006; Shu-Sheng \& Hsiu-Mei, 2011; Pozón-López, Kalinic, Higueras-Castillo, \& Liébana-Cabanillas, 2019).

\section{Objectives and research questions}

Among the various factors that might influence involvement in MOOCs, the importance of motivations could lie in their effect on variables that condition the success of the MOOC experience. Understanding the nature and different levels of motivations and their relations with the variables associated with technology acceptance (PU, PEU, ATU, LOY, and SAT) is fundamental if we are to gain insight and facilitate more efficient learning and teaching in MOOCs. Moreover, Nikou and Economides (2017) highlighted the link between SDT and technology acceptance in new learning environments.

Student participation and interaction are relevant in the online learning context given that they evidence knowledge building and sharing (Ergün \& Avc1, 2018). Hence, the present study also includes real (rather than intended) participation and interaction data, in line with the research design employed by Barba et al. (2016), in which video hits and quiz attempts were used as indices of course participation.

So, our main objective is to explore the relationships between motivation and both perceptual variables related to technology acceptance and actual participation in MOOCs, providing a background for further research; i.e. to examine the links between motivations and the development of intention to use, and real use of these educational tools.

Combining questionnaire data and behavioral data from the platform, the present study aims to answer the following research questions:

- RQ1: What are the main motivations of the participants who follow the MOOC?

- RQ2: Are differences in technology acceptance variables associated with different motivations?

- RQ3: Are differences in participation associated with different motivations?

Exploring motivations and their relations to other variables is a first step to improve modeling and design measures to enhance the MOOC experience. 


\section{Methodology}

Our methodology combines two different approaches. Once the MOOC had ended, we delivered a questionnaire to participants to learn how they perceived their motivations and find out about their experience of the course. We then analyzed platform log data of actual participation in the MOOC activities (such as viewing materials, publishing content, participating in activities, etc.) to complement the perceptual data.

This combination of objective course participation data with participants' perceptions of the course provides an interesting methodological approach to our research questions. Bozkurt et al. (2017) indicated that data mining methodologies currently influence the emerging methodological paradigms in MOOC research. However, our study combines both data types in order to offer a more comprehensive response to the research questions.

\subsection{Description of the MOOC}

The University of Granada (Spain) has developed its own platform-Abierta (https://abierta.ugr.es/) — by adapting Moodle software in order to offer MOOCs. Their most successful MOOC is "The Alhambra: history, art and heritage". Open to anyone interested in the topic with no prerequisites, the aim of the MOOC is to facilitate the acquisition of in-depth knowledge of the monument from a multidisciplinary perspective. We have classified this as an XMOOC because of its clearly structured, transmissive nature, which focuses mainly on the educational platform and its freemium component for obtaining credits (Bozkurt et al. 2017).

The course lasts six weeks, with 75 hours of work in six modules. Course materials consist mainly of textual information and videos: around 50 videos of approximately 3 minutes each. The MOOC combined quality contents and tests with a more dynamic, emerging, social, student participation model that encouraged learners to publish their own content on the platform. Debates and social activities were promoted using social media and forums: the coffee forum, where participants could socialize with other participants and teachers in an informal way; and the support forum, where students could receive support from facilitators and peers.

Evaluation was based on self-assessment tests (one per module and one final test). Learners who followed the weekly schedule and completed the activities proposed were entitled to receive certification. Additionally, University of Granada students could obtain elective credits for their degree programs - on payment of a small fee.

The first edition of the course was delivered in spring 2015, with more than 10000 registered users (44\% completion rate). The second edition (spring 2016) had more than 11000 registered users $(65 \%$ completion rate).

\subsection{Data collection}

Our study is based on the 2016 edition of the MOOC. In the last week of the course, a questionnaire designed on Google Drive was distributed to all registered users via email, the platform, and the Facebook group. Data collection was conducted in accordance with University of Granada ethical principles.

Some 2084 students (64.2\% female; $35.8 \%$ male; $30.5 \%$ of those completing the course) responded to the questionnaire. Respondent age ranged up to 72 years, with a mean of 30.3 (SD: 13.44); 26\% had had previous experience of MOOCs. 
A database combined student perception data - drawn from the questionnaire- with objective data about student behavior - obtained by collecting log information on participants' activities undertaken on the platform. The nature of the information provided by the platform is characterized by its variety and volume: a single day's activity on the MOOC generated more than 50000 entries with information about actions such as "modules seen", "user evaluation activities", "attempt done", "completion of the course", and so on. These logs were processed so they could be combined with survey variables and stored in a single database.

As mentioned earlier, to explore participation, we include these learning behaviors: visualization of course materials, messages created and content published on the platform, actions in the coffee forum and in the support forum. These cover the main actions required by the MOOC design. They were measured in absolute terms as the number of actions per item. The variables employed were:

- visualization of course materials (conceptualized as actions to visualize material in different formats in the MOOC), in line with Barba at al. (2016);

- messages created on the platform and publication of content on the platform (as indicators of creative participation in the course);

- actions in social forums: the so-called coffee forum and the support forum (as indicators of social interaction and supportive search, respectively).

\subsection{Measures}

In the questionnaire (see Appendix), we based our measure of motivation on the Spanish version (Nuñez Alonso, Martín-Albo Lucas, \& Navarro Izquierdo, 2005) of the Academic Motivation Scale (Vallerand et al., 1992). We chose a single item to measure EM (external regulation), with the item that most perfectly fitted the definition and was most relevant to our context: "I did the course to obtain credits" (M01), which conceives participation as an activity to obtain external rewards. The use of single-item scales is adequate if the construct being measured is unambiguous and appears simple to the respondent - as it was in this case for EM-(Wanous, Reichers, \& Hudy, 1997; Reichheld, 2003; Barba et al., 2016). As Sarstedt and Wilczynski (2009) note, while single-item measures are not appropriate for complex constructs, in terms of reliability their performance is acceptable for simple constructs. The most commonly mentioned advantages of single-item measures refer to the simplicity and brevity of surveying respondents and the lower associated costs (Wanous et al., 1997). Single items are generally associated with lower levels of mental fatigue which yield higher response rates, more completed questionnaires and, thus, greater survey efficiency (Bergkvist \& Rossiter, 2007; Drolet \& Morrison, 2001).

Internal motivation towards knowledge has been connected with concepts such as curiosity or motivation to learn (Gottfried, 1985) and refers to performing an activity for the pleasure that is experienced while learning, exploring or trying to understand something new (Vallerand et al., 1992). Two items were used to measure IM-to know. Motivation items were answered on a 7-point Likert scale.

The technology acceptance variables PU and PEU were measured using 4- and 3-item scales, respectively, adapted from Koufaris, Kambil and LaBarbera (2002), and previously used by Del Barrio-García et al. (2015), Gao and Wu (2010) and Panopoulos and Sarri (2013), among others. Our ATU scale was adapted from the 3-item scale proposed by Chen, Gillenson and Sherrell (2002), which has been used in educational research by Pituch and Lee (2006), Freeze, Alshare, Lane and Wen (2010), Chen (2011), and Arquero et al. (2017). The LOY variable for student loyalty was measured using the classic 4-item scale developed by Zeithaml, Berry and 
Parasuraman (1996). This has two components: behavioral intention to use the MOOC (BIU) and willingness to recommend it (WIR). Similar scales have been reported elsewhere (Adam \& Nel, 2009; Letcher \& Neves, 2010; Perin, Sampaio, Simões, \& de Pólvora, 2012; Arquero et al., 2017). Finally, e-learning Satisfaction (eSAT) was measured using the 4-item scale initially proposed by Szymanski and Hise (2000), and used by Dehghan, Dugger, Dobrzykowski and Balazs (2014), Islam (2014) and Arquero et al. (2017) in the field of education. All of these items were designed to be answered on an 11-point Likert scale, ranging from 0 (totally disagree) to 10 (totally agree). For the learning satisfaction scale, an 11-point semantic differential scale was used.

\section{Results}

Prior to performing the data analysis, the validity and reliability of the scales were examined by conducting confirmatory factor analysis (CFA) with Lisrel 8.8 software. We used the robust maximum likelihood (RML) estimation method, as the variables in this case did not follow a normal multivariate distribution (Del Barrio \& Luque, 2012; Hair. et al., 2014). The overall goodness-of-fit indices were within recommended limits (SB Chi-Square: 1190.19; df: 169; pvalue: 0.00; RMSEA: 0.05; CFI: 0.99), the standardized loadings were significant $(\mathrm{p}<0.01)$ and high (>0.70) (Del Barrio \& Luque, 2012; Hair et al., 2014), except in two cases (PU01 and ATU02) with lower values. Notwithstanding, in order to maintain the content validity of the constructs, it was decided to keep them. In addition, composite reliability $(\mathrm{CR})$ and average variance extracted (AVE) were both above the recommended limits of 0.80 and 0.50 , respectively (see Appendix). These findings provided evidence of our scales' convergent validity. Finally, the constructs were shown to have adequate discriminant validity, according to the Fornell \& Larcker (1981) criterion.

Once the psychometric properties of the scales had been analyzed, we determined the value of each variable by calculating the mean of all constituent items. Scores for ATU, LOY and SAT are especially high with a mean in excess of 9 out of 10. The PU and PEU scores had a lower mean with greater variability. Intrinsic motivation had a mean in excess of 9; EM scoresgiven their bimodal distribution - had a much lower mean (6.72) with a higher standard deviation (SD: 3.86). The sharp contrast between IM and EM is why we need to further explore the differences in relation to the other variables in the study (see Table 1, Panel A).

Table 1 (Panel B) shows the correlation analysis between the technology acceptance variables (perceptual variables). Intrinsic motivation presents higher correlations with other variables than EM does. The difference is particularly pronounced for SAT, LOY and PEU; and somewhat lower for PU and ATU.

Table 1. Descriptive statistics for motivational and technology acceptance variables and Spearman correlations 
This is an authors' version of the article published in "Interactive Learning Environments". The final authenticated version is available online at: $h$ ttp://dx.doi.org/10.1080/10494820.2020.1799020

\begin{tabular}{|c|c|c|c|c|c|c|c|}
\hline \multicolumn{8}{|c|}{ Panel A Descriptive statistics } \\
\hline & $P U$ & $P E U$ & $A T U$ & $L O Y$ & $S A T$ & $E M$ & $I M$ \\
\hline Mean & 8.43 & 8.75 & 9.31 & 9.30 & 9.07 & 6.72 & 9.04 \\
\hline SD & 1.29 & 1.08 & 0.89 & 0.97 & 1.06 & 3.86 & 1.35 \\
\hline No. items & 4 & 3 & 3 & 4 & 4 & 1 & 2 \\
\hline \multicolumn{8}{|c|}{ Panel B Correlation analysis (Spearman) } \\
\hline & $P U$ & $P E U$ & $A T U$ & $L O Y$ & $S A T$ & $E M$ & $I M$ \\
\hline PU & 1 & $.482^{* *}$ & $.507^{* *}$ & $.508^{* *}$ & $.496^{* *}$ & $.208^{* *}$ & $.310^{* *}$ \\
\hline PEU & & 1 & $.596^{* *}$ & $.505^{* *}$ & $.490^{* *}$ & $.125^{*}$ & $.351^{* *}$ \\
\hline ATU & & & 1 & $.653^{* *}$ & $.558^{* *}$ & $.171^{* *}$ & $.390^{* *}$ \\
\hline LOY & & & & 1 & $.652^{* *}$ & $.092^{* *}$ & $.487^{* *}$ \\
\hline SAT & & & & & 1 & $.089^{* *}$ & $.542^{* *}$ \\
\hline EM & & & & & & 1 & $-.093^{* *}$ \\
\hline
\end{tabular}

The correlations between motivation scores indicate that although a negative relationship exists between EM and IM, this is very weak (-.093). This suggests that the mutually exclusive, continuum view of motivation, as proposed by the SDT, is not supported by our results.

Table 2 presents descriptive statistics for the participation variables. Note the tremendously wide ranges in these variables: e.g. activity in forums ranges from 0 to 1683 messages, with a mean close to 11 . In general terms, social interaction in forums is quite frequent and participants tend not to publish content on their own.

Table 2. Descriptive statistics for actual participation

\begin{tabular}{llrr}
\hline & & Mean (SD) & min-max (range) \\
\hline Content interaction & Module viewing & $74.05(79.47)$ & $0-2125$ \\
& Topic viewing & $35.76(53.23)$ & $0-1560$ \\
Creative participation & Messages created & $0.57(2.61)$ & $0-45$ \\
& Publication of content & $0.7(3.13)$ & $0-52$ \\
Social interaction & Act. In coffee forum & $10.89(62.4)$ & $0-1682$ \\
Supportive search & Act. In support forum & $2.48(19.32)$ & $0-563$ \\
\hline
\end{tabular}

We performed a cluster analysis (k-means procedure) to obtain a better picture of the motives of students enrolled on the MOOC and classify them to test differences required in order to answer RQ2 and RQ3. This resulted in three clusters (Table 3).

Table 3. Clusters and descriptive statistics by group

\begin{tabular}{lrrr}
\hline & $1-I M$ & 2-mainly EM & 3-both high \\
\hline EM & $0.60(1.09)$ & $8.73(1.64)$ & $8.79(1.62)$ \\
IM-to know & $9.46(0.90)$ & $6.35(1.38)$ & $9.42(0.72)$ \\
N: & 526 & 264 & 1294 \\
Female & $63.7 \%$ & $58.0 \%$ & $65.7 \%$ \\
Male & $36.3 \%$ & $42.0 \%$ & $34.3 \%$ \\
\hline
\end{tabular}




\begin{tabular}{llll}
\hline Aver. Age & $41.7(14.4)$ & $23.7(7.16)$ & $27.1(11.0)$ \\
\hline
\end{tabular}

Notes: mean (SD)

The first cluster is made up of participants with very high IM (9.46) and very low EM (0.6), suggesting that their sole source of motivation is intrinsic. The mean age of these participants is higher than that of the other two groups. Cluster number 2 is defined by high EM (8.73) and mid-level IM (6.35, the lowest mean of the groups), so the predominant source of motivation is EM. The participants in this cluster are younger than their peers and the proportion of males is higher than in the other two clusters. Number 3 is defined by high IM and high EM (the former are as high as cluster 1, and the latter are as high as cluster 2). The male:female ratios is similar to cluster 1, but the participants are younger (mean 27.1 years). Cluster 3 is by far the largest group, which reinforces the view that these two supposedly alternative sources of motivation can simultaneously be present at high levels.

Table 4 Panel A presents the mean scores for acceptance variables by cluster. Although the scores fall, the mean for all students is above 7 in all variables. Students who are highly motivated by all sources (cluster 3-both_high) systematically show the highest values for all acceptance variables. Contrariwise, those presenting EM as their dominant source of motivation (2-main EM cluster) systematically present the lowest scores of all the groups. Among the acceptance scores for group 1, only those with IM are in the mid-range, but they are closer to the results obtained for cluster number 3-both high. The biggest differences can be found in PU (8.67 for cluster 3 vs 7.79 for cluster 2 ) and eSAT (8.07, cluster 3 vs 8.07, cluster 2).

Table 4. Studied variables by cluster

\begin{tabular}{lrrrr}
\hline Panel A & \multicolumn{1}{c}{ I-IM } & 2-mainly EM & 3-both high & $K$-W \\
Acceptance variables & $8.14(1.41)$ & $7.79(1.31)$ & $8.67(1.16)$ & .000 \\
PU & $8.73(1.06)$ & $8.03(1.24)$ & $8.89(0.98)$ & .000 \\
PEU & $9.25(0.96)$ & $8.81(1.11)$ & $9.43(0.74)$ & .000 \\
ATU & $9.26(1.1)$ & $8.6(1.19)$ & $9.45(0.78)$ & .000 \\
LOY & $9.08(1.05)$ & $8.07(1.3)$ & $9.26(0.88)$ & .000 \\
eSAT & & & & \\
\hline Panel B & $1-I M$ & 2-mainly EM & 3-both high & $K$-W \\
Participation variables & $99.45(108.91)$ & $45.11(32.88)$ & $69.64(68.45)$ & .000 \\
Module viewing & $41.83(75.27)$ & $26.53(22.01)$ & $35.18(46.18)$ & .000 \\
Topic viewing & $0.95(3.07)$ & $0.12(0.71)$ & $0.52(2.63)$ & .000 \\
Messages created & $1.2(3.64)$ & $0.14(0.8)$ & $0.62(3.18)$ & .000 \\
Publication of content & $20.98(91.03)$ & $2.24(5.05)$ & $8.55(53.3)$ & .000 \\
Act. In coffee forum & $3.5(26.21)$ & $0.7(2.65)$ & $2.43(17.89)$ & .004 \\
Act. In support forum &
\end{tabular}

Notes: mean (SD), K-W: Kruskall-Wallis test significance.

Actual participation variable data show that group number 1-IM participants-presents a more active profile. Primarily EM participants systematically present the lowest levels of 
participation. In this case, high EM seems to be associated with less active participation, even in the presence of high IM.

To summarize the results to answer our research questions, with regard to RQ1, we find that those participants who answered the questionnaire generally present high IM. Even those who were classified in the mainly EM group presented a mean 6.35 for IM. However, the most numerous group presented very high levels of both motivations, which clearly contradicts the view proposed by SDT. The third group could be defined as only IM as they presented a pattern of motivations more consistent with the SDT: high IM and very low EM.

Research question 2 clearly has an affirmative response as both sources of motivation-IM to a higher degree - seem to be associated with higher acceptance variable scores. For these variables, the two sources of motivation are present and seem to have a summative effect.

Research question 3 focused on the relationship between motivation and participation. High IM students tend to interact more frequently with contents, are more active (creating more messages or publishing more content) and interact more frequently with others in forums.

Contrariwise, EM appears to be associated with lower levels of participation. Thus, high EM students tend to interact less with MOOC contents, participate less actively (with messages or publications) and interact much less frequently in forums, even when they present high levels of IM. So the answer to RQ3 is affirmative for both motivations. It appears that IM is associated with increased participation, whereas EM seems to be associated with lower levels of interaction and participation, even in the presence of high IM. These results are consistent with an instrumental use of the course for external purposes, for which participation is the means to achieve the goal of finishing the course and obtaining credits.

Table 5 presents the correlations between motivation and acceptance variables by cluster. As these results indicate, the pattern of correlations varies systematically by group. For cluster 1 (IM), IM is positively linked to all acceptance variables, and the correlations with loyalty (the variable that includes intention to use) and satisfaction are especially high. However, the relationships between EM and acceptance are negative, weak, but statistically significant except for PU. In contrast, for cluster 2-mainly EM-except for PU-there is no association between IM and acceptance variables, and there are positive associations between EM and all acceptance variables. As could be expected after the previous results, for the third group (3both high) relationships between both sources of motivation and all acceptance variables are positive. Note that the IM-EM relationship is also different for each group.

Table 5. Correlations between the motivation-acceptance variables by cluster

\begin{tabular}{lcccccc}
\hline & \multicolumn{2}{c}{ l-IM } & \multicolumn{2}{c}{ 2-mainly EM } & \multicolumn{2}{c}{ 3-both high } \\
& EM & IM & EM & IM & EM & IM \\
\hline PU & -0.041 & $.301^{* *}$ & $.231^{* *}$ & $.127^{* *}$ & $.228^{* *}$ & $.276^{* *}$ \\
PEU & $-.174^{* *}$ & $.301^{* *}$ & $.383^{* *}$ & -0.012 & $.221^{* *}$ & $.301^{* *}$ \\
ATU & $-.167^{* *}$ & $.383^{* *}$ & $.432^{* *}$ & -0.079 & $.287^{* *}$ & $.389 * *$ \\
LOY & $-.168^{* *}$ & $.491^{* *}$ & $.339^{* *}$ & 0.041 & $.204^{* *}$ & $.469 * *$ \\
\hline
\end{tabular}




\begin{tabular}{lrrrrrr}
\hline eSAT & $-.145^{* *}$ & $.498^{* *}$ & $.227 * *$ & 0.081 & $.203 * *$ & $.508^{* *}$ \\
EM & 1 & $-.149 * *$ & 1 & -0.109 & 1 & $.134 * *$ \\
\hline
\end{tabular}

Therefore, as additional evidence for RQ2, the motivation type influences both the mean level of acceptance and the relationship between sources of motivation and acceptance. This could shine some light on the differing results reported in the literature. In as much as the specific sample used in each study presents a different kind of motivation, the relationships between variables could be different, and this could be explained by taking the mix of motivations into account.

\section{Discussion and implications}

As Alario-Hoyos, Estévez-Ayres, Pérez-Sanagustín, Kloos and Fernández-Panadero (2017) and Martin et al (2018) note, the heterogeneous population of learners on MOOCs requires indepth analysis to obtain information about learner motivation in order to help design more attractive courses and promote engagement. Earlier studies have indicated that MOOC participants present a combination of motivations. In contrast to the unidimensional assumptions of SDT (e.g. Ryan \& Deci, 2000), our results support that assertion. Many students who completed the course presented high levels of both IM and EM; in fact, this defines the cluster that included the vast majority of our participants. In line with Chamberlin and Parish (2011), a high percentage of these committed students value the opportunity to obtain credit recognition is an extra motivation even though their principal motive is interest in the contents per se (i.e. IM). Thus, our results only partly support Wang and Baker's (2015) conclusions. Intrinsic motivation is of the highest importance but certification obtained after completion is also of major importance for many students.

As Joo et al. (2018) state, external rewards, certificates and credits, must be examined through external regulation, a situation in which no action is likely to occur without external compensation. As a practical implication, we would assert that certification, credits or similar rewards can be an effective additional source of motivation that could improve the completion rates for these courses.

Abdullatif and Velázquez-Iturbide (2019) found a negative relationship between intention to use (a component of our loyalty variable) and EM, and a positive relationship between it and IM. Our results confirm this link (positive between IM and both attitude and loyalty) but also reveal a positive link - very weak, but positive-between EM and acceptance variables. If we look at EM and IM as alternative sources of motivation, EM alone is related to higher levels of acceptance (cluster 1-IM, presents systematically higher scores than cluster 2-mainly EM) and it is more clearly connected (correlations are positive and present higher coefficients than EM). However, the effect of EM is summative over the effect of IM alone, with cluster 3-high IM $\&$ high EM-being the group that presents the highest mean scores on all acceptance variables. In line with $\mathrm{Wu}$ and Cheng (2017), this suggests that including both types of motivation in a model, instead of only one, could result in improved accuracy.

When studying the connections between motivation and actual participation behavior, both sources of motivation appear to be systematically associated with differences. High IM participants interact more frequently with the platform contents, tend to be more actively involved in forums and are more participative, which is consistent with a motivation originating 
in the satisfaction experienced when learning new things. In contrast, mainly EM participants present the lowest values on actual usage variables. In their case the effect of EM is negative, given that the participants in cluster 3 (high IM \& EM) are less likely to be active than those in cluster 1 (only IM).

This is consistent with the theoretical definition of external regulation: the activity is performed to obtain a separable outcome (credits), which is the students' real objective. Therefore, the level of interaction is just that needed to finish the course and gain the credits awarded. So, we cannot conclude, as Xiong et al. (2015) did, that IM and EM are both significant positive predictors of student engagement in the course.

Consequently, our data complement results reported by Tu and McIsaac (2002), who argued that high IM levels are related to greater persistence, better ability to cope with failure, a more positive self-perception, and higher quality task engagement. Furthermore, IM also associates with better acceptance of MOOC technology and more active participation, but we must take into account the fact that for high externally-driven students it is this level of motivation that is linked to acceptance levels. Results suggest that, when developing acceptance models, different mixes of motivations should be considered in order to generate more accurate models. As Brooker et al. (2018) stress, MOOC designers should consider how specific learning objects and structure meet or do not meet the different needs and motivations of participants. So, for high IM students, course design should focus on the generation of challenging, quality contents (see for instance the design principles proposed by Martin et al. [2018], which focus on selfdetermined students). However, if the proportion of extrinsically-motivated students is high, the course design should also allow for a more straightforward, structured way to complete it, given that these students present a different pattern of interaction with the contents, and different objectives. These results would support the call for a personalized learning movement, a trend highlighted by the NMC Horizon Report - Higher Education Edition (Adams et al. 2017), and elsewhere. For example, the incorporation of Adaptative Learning Technologies to MOOC design could foster the adaptation of the contents and activities to the different sets of student motivations and skills.

\section{Limitations \& future research}

In this study, we were only able to administer the questionnaire at the end of the course and therefore the vast majority of respondents were individuals who had already or were about to complete it. This prevented us from addressing the issue of attrition-one of the main MOOCrelated research topics (Gütl, Rizzardini, Chang, \& Morales, 2014; Deshpande \& Chukhlomin, 2017). However, given the high percentage of enrolled students who completed the course, we would suggest that our approach is of great interest to understand how motivations vary in individuals who effectively succeed in following a MOOC. As Barba et al. (2016) pointed out, embedding questions in ongoing course materials could provide new opportunities to analyze the dynamics of the links between motivation, participation and performance by taking into account those participants who could drop out. Future research should consider access to the MOOC from the beginning so as to analyze the evolution in motivation and the other variables included in the study over time. Thus, it would be possible to better understand how the variables are connected and to design strategies to improve technology acceptance.

Motivation is a complex concept consisting of a multiplicity of components. As Yuan and Powell (2013, p. 9) argued, additional factors that influence MOOC student motivation levels could be taken into account. These might include "future economic benefits, development of personal or professional identity, challenge and achievement, enjoyment and fun", among 
others. Future research should take these factors into account in order to understand personal and contextual factors that determine MOOC technology acceptance and participation.

Our research was conducted in a context with relatively little diversity among the students. Similar studies in more complex and diverse contexts could provide additional evidence on this. Future research could also take advantage of these results in order to improve the design of models that explain participation in MOOCs.

\section{Acknowlegments}

We gratefully acknowledge the help of the Resource Production Centre for the Digital University (CEPRUD) of the University of Granada for providing access to the MOOC database.

\section{References}

Abdullatif, H., \& Velázquez-Iturbide, J.Á. (2020). Relationship between motivations, personality traits and intention to continue using MOOCs. Education and Information Technologies. doi:10.1007/s10639-020-10161-Z

Adam, S., \& Nel, D. (2009). Blended and online learning: student perceptions and performance. Interactive technology and smart education, 6(3), 140-155. doi:10.1108/17415650911005366

Adams Becker, S., Cummins, M., Davis, A., Freeman, A., Hall Giesinger, C., \& Ananthanarayanan, V. (2017). NMC Horizon Report: 2017 Higher Education Edition. Austin, Texas: The New Media Consortium. Retrieved from https://www.sconul.ac.uk/sites/default/files/documents/2017-nmc-horizon-report-he-EN.pdf Ajzen, I. (1988). Attitudes, Personality and Behavior. Chicago: The Dorsey Press. Alario-Hoyos, C., Estévez-Ayres, I., Pérez-Sanagustín, M., Kloos, C. D., \& FernándezPanadero, C. (2017). Understanding learners' motivation and learning strategies in MOOCs. International Review of Research in Open and Distributed Learning, 18(3), 119-137. doi:10.19173/irrodl.v18i3.2996

Alraimi, K. M., Zo, H., \& Ciganek, A. P. (2015). Understanding the MOOCs continuance: The role of openness and reputation. Computers \& Education, 80, 28-38. doi:10.1016/j.compedu.2014.08.006

Arquero, J. L., del Barrio-García, S., \& Romero-Frías, E. (2017). What Drives Students' Loyalty-Formation in Social Media Learning Within a Personal Learning Environment Approach? The Moderating Role of Need for Cognition. Journal of Educational Computing Research, 55(4), 495-525. doi:10.1177/0735633116672056

Arquero, J. L., Fernández-Polvillo, C., Hassall, T., \& Joyce, J. (2015). Vocation, motivation and approaches to learning: a comparative study. Education + Training, 57(1), 13-30. Retrieved from https://www.emeraldinsight.com/doi/abs/10.1108/ET-02-2013-0014 Assael, H. (1984). Consumer Behavior and Marketing Action (Second Edition). Boston, Mass.: Kent Publishing. 
Bali, M. (2014). "MOOC Pedagogy: Gleaning Good Practice from Existing Moocs". MERLOT Journal of Online Learning and Teaching, 10(1), 44.

Bandura, A. (2006). Going global with social cognitive theory: From prospect to paydirt. In S. I. Donaldson, D. E. Berger, \& K. Pezdek (Eds.), The rise of applied psychology: New frontiers and rewarding careers (pp. 53-70). Mahwah, NJ: Erlbaum. Retrieved from https://www.uky.edu/ eushe2/Bandura/Bandura2006Global.pdf

Barba, P. D., Kennedy, G. E., \& Ainley, M. D. (2016). The role of students' motivation and participation in predicting performance in a MOOC. Journal of Computer Assisted Learning, 32(3), 218-231. doi:10.1111/jcal.12130.

Bekele, T. A. (2010). Motivation and Satisfaction in Internet-Supported Learning Environments: A Review. Educational Technology \& Society, 13(2), 116-127. Retrieved from https://www.jstor.org/stable/pdf/jeductechsoci.13.2.116.pdf

Bergkvist, L., \& Rossiter, J. R. (2007). The predictive validity of multiple-item versus singleitem measures of the same constructs. Journal of Marketing Research, 44(2), 175-184.

Bozkurt, A., Akgün-Özbek, E., \& Zawacki-Richter, O. (2017). Trends and patterns in massive open online courses: Review and content analysis of research on MOOCs (20082015). International Review of Research in Open and Distributed Learning: IRRODL, 18(5), 118-147.

Brooker, A., Corrin, L., De Barba, P., Lodge, J., \& Kennedy, G. (2018). A tale of two MOOCs: How student motivation and participation predict learning outcomes in different MOOCs. Australasian Journal of Educational Technology, 34(1): 73-87. doi: 10.14742/ajet.3237

Bulfin, S., Pangrazio, L., \& Selwyn, N. (2014). Making 'MOOCs': The construction of a new digital higher education within news media discourse. International Review of Research in Open and Distributed Learning, 15(5), 290-305.

Castañeda, J. A., Muñoz-Leiva, F., \& Luque, T. (2007). Web Acceptance Model (WAM): Moderating effects of user experience. Information \& Management, 44(4), 384-396. doi:10.1016/j.im.2007.02.003

Chamberlin, L., \& Parish, T. (2011). MOOCs: Massive Open Online Courses or massive and often obtuse courses? eLearn, 2011, 8. doi:10.1145/2016016.2016017

Chen, J. L. (2011). The effects of education compatibility and technological expectancy on elearning acceptance. Computers \& Education, 57(2), 1501-1511. doi:10.1016/j.compedu.2011.02.009

Chen, L., Gillenson, M. L., \& Sherrell, D. L. (2002) Enticing online consumer: an expected technology acceptance perspective. Information \& Management, 39(8), 705-719. doi:10.1016/S0378-7206(01)00127-6

Clow, D. (2013). MOOCs and the funnel of participation. In Proceedings of the Third International Conference on Learning Analytics and Knowledge (pp. 185-189). ACM. doi: $10.1145 / 2460296.2460332$

Cokley, K. O. (2000). Examining the validity of the Academic Motivation Scale by comparing scale construction to self-determination theory. Psychological Reports, 86, 560564. doi:10.2466/pr0.2000.86.2.560 
This is an authors' version of the article published in "Interactive Learning Environments". The final authenticated version is available online at: $h$ ttp://dx.doi.org/10.1080/10494820.2020.1799020

Davis, F. D. (1993). User acceptance of information technology system characteristics. User perceptions and behavioral impacts. International Journal of Man-Machine Studies, 38(3), 475- 487. doi:10.1006/imms.1993.1022

Davis, F. D., Bagozzi, R. P., \& Warshaw, P. R. (1989). User Acceptance of User technology: A Comparison of Two Theoretical Models. Management Science, 35 (8), 982-1002. Retrieved from https://www.jstor.org/stable/2632151

De Freitas, S. I., Morgan, J., y Gibson, D. (2015). Will Moocs Transform Learning and Teaching in Higher Education? Engagement and Course Retention in Online Learning Provision. British Journal of Educational Technology, 46(3), 455-471.

https://doi.org/10.1111/bjet.12268

DeBoer, J., Stump, G. S., Seaton, D., Ho, A., Pritchard, D. E., \& Breslow, L. (2013). Bringing student backgrounds online: MOOC user demographics, site usage, and online learning. In Proceedings of Educational Data Mining 2013 (pp. 312-313). Retrieved from http://www.educationaldatamining.org/EDM2013/proceedings/EDM2013Proceedings.pdf

Deci, E. L., \& Ryan, R. M. (1980). Self-determination theory: When mind mediates behavior. Journal of Mind and Behavior, 1, 33-43. Retrieved from https://www.jstor.org/stable/43852807

Deci, E. L., \& Ryan, R. M. (1985). Intrinsic motivation and self-determination in human behavior. New York: Plenum Press. doi: 10.1007/978-1-4899-2271-7_2

Dehghan, A., Dugger, J., Dobrzykowski, D., \& Balazs, A. (2014). The antecedents of student loyalty in online programs. International Journal of Educational Management, 28(1), 15-35. doi:10.1108/IJEM-01-2013-0007

Del Barrio, S., \& Luque, T. (2012). Análisis de Ecuaciones Estructurales. In T. Luque (Ed.), Técnicas de Análisis de datos en investigación de mercados (pp. 525-610). Barcelona: Pirámide.

Del Barrio-García, S., Arquero, J. L., \& Romero-Frías, E. (2015). Personal learning environments acceptance model: The role of need for cognition, e-learning satisfaction and students' perceptions. Educational Technology and Society, 18(3), 129-141. doi:10.1177/0735633116672056

Deshpande, A., \& Chukhlomin, V. (2017). What Makes a Good MOOC: A Field Study of Factors Impacting Student Motivation to Learn. American Journal of Distance Education, 31(4), 275-293. doi:10.1080/08923647.2017.1377513

Downes, S. (2005). An Introduction to Connective Knowledge. Retrieved from https://www.downes.ca/cgi-bin/page.cgi?post $=33034$

Drolet, A. L., \& Morrison, D. G. (2001). Do we really need multiple-item measures in service research?. Journal of Service Research, 3(3), 196-204.

Ebben, M., \& Murphy, J. S. (2014). Unpacking MOOC scholarly discourse: A review of nascent MOOC scholarship. Learning, Media and Technology, 39(3), 328-345.

Ergün, E., \& Avc1, Ü. (2018). Knowledge Sharing Self-Efficacy, Motivation and Sense of Community as Predictors of Knowledge Receiving and Giving Behaviors. Educational Technology \& Society, 21(3), 60-73. Retrieved from https://www.jstor.org/stable/26458507

Fırat, M., Kılınç, H., \& Yüzer, T. V. (2018). Level of intrinsic motivation of distance education students in e-learning environments. Journal of Computer Assisted Learning, 34(1), 63-70. doi: 10.1111/jcal.12214 
Fishbein, M., \& Ajzen, I. (1974). Attitudes towards objects as predictors of single and multiple behavioral criteria. Psychological Review, 81(1), 59-74. doi:10.1037/h0035872

Fornell, C. \& Larcker, D.F. (1981). Evaluating structural equation models with unobservable variables and measurement error. Journal of Marketing Research, 18 (February), 39-50.

Fournier, H., y Kop, R. (2015). MOOC Learning Experience Design: Issues and Challenges. International Journal on E-Learning, 14(3), 289-304

Freeze, R. D., Alshare, K. A., Lane, P. L., \& Wen, H. J. (2010). IS success model in elearning context based on students' perceptions. Journal of Information Systems Education, 21(2), 173-184. Retrieved from https://eric.ed.gov/?id=EJ893896

Gao, Y., \& Wu, X. (2010). Perceived value of educational hypermedia: An exploratory study. American Journal of Business Education, 3(8), 13-20.

Gašević, D., Kovanović, V., Joksimović, S., \& Siemens, G. (2014). Where is research on massive open online courses headed? A data analysis of the MOOC research initiative. International Review of Research in Open and Distance Learning, 15(5), 134-176. doi:10.19173/irrodl.v15i5.1954

Gomez-Zermeno,M., \& Aleman, L. (2016). Research analysis on Mooc course dropout and R. Turkish Online Journal of Distance Education, 17(4), 3-14.

Gottfried, A. E. (1985). Academic intrinsic motivation in elementary and junior high school students. Journal of Educational Psychology, 77(6), 631-645. doi:10.1037/00220663.77.6.631

Gütl, C., Rizzardini, R.H., Chang, V., \& Morales, M. (2014). Attrition in MOOC: Lessons learned from drop-out students. In International Workshop on Learning Technology for Education in Cloud (pp. 37-48). Springer International Publishing. doi: 10.1007/978-3-31910671-7_4

Hair, J. F., Black, W. C., Babin, B. J., \& Anderson, R. E. (2014). Multivariate Data Analysis. 7th Ed. Pearson Education Limited.

Han, H., \& Ryu, K. (2009). The roles of the physical environment, price perception, and customer satisfaction in determining customer loyalty in the family restaurant industry. Journal of Hospitality and Tourism Research, 33(4): 487-510. doi:10.1177/1096348009344212

Helgesen, Ø., \& Nesset, E. (2007) Images, satisfaction and antecedents: Drivers of student loyalty? A case study of a Norwegian university college. Corporate Reputation Review, 10(1), 38-59. doi:10.1057/palgrave.crr. 1550037

Hennig-Thurau, T., Langer, M. F., \& Hansen, U. (2001). Modeling and managing student loyalty an approach based on the concept of relationship quality. Journal of Service Research, 3(4), 331-344. doi:10.1177/109467050134006

Hew, K. F., \& Cheung,W. S. (2014). Students' and instructors' use of massive open online courses (MOOCs): Motivations and challenges. Educational Research Review, 12, 45-58. https://doi.org/10.1016/J.EDUREV.2014.05.001.

Hsu, J. Y., Chen, C. C., \& Ting, P. F. (2018). Understanding MOOC continuance: An empirical examination of social support theory. Interactive Learning Environments, 26(8), 1100-1118. doi:10.1080/10494820.2018.1446990 
This is an authors' version of the article published in "Interactive Learning Environments". The final authenticated version is available online at: $h$ ttp://dx.doi.org/10.1080/10494820.2020.1799020

Islam, A. A. (2014). Validation of the Technology Satisfaction Model (TSM) Developed in Higher Education: The Application of Structural Equation Modeling. International Journal of Technology and Human Interaction, 10(3), 44-57. doi:10.4018/ijthi.2014070104

Joo, Y. J., So, H. J., \& Kim, N. H. (2018). Examination of relationships among students' selfdetermination, technology acceptance, satisfaction, and continuance intention to use KMOOCs. Computers \& Education, 122, 260-272. doi:10.1016/j.compedu.2018.01.003

Kagan, J. (1972). Motives and development. Journal of Personality and Social Psychology, 22(1), 51-66. doi:10.1037/h0032356

Keller, J. M. (1983). Motivational design of instruction. In C. M. Reigeluth (Ed.), Instructional design theories and models: An overview of their current status (pp. 384-434). Hillsdale, NJ: Lawrence Erlbaum Associates. doi:10.1002/pfi.4160260902

Khan, I. U., Hameed, Z., Yu, Y., Islam, T., Sheikh, Z., \& Khan, S. U. (2017). Predicting the acceptance of MOOCs in a developing country: Application of task-technology fit model, social motivation, kimand self-determination theory. Telematics and Informatics, 35(4), 964978. doi:10.1016/j.tele.2017.09.009

Kim, C., Park, S. W., Cozart, J., \& Lee, H. (2015). From motivation to engagement: The role of effort regulation of virtual high school students in mathematics courses. Journal of Educational Technology \& Society, 18(4), 261.

Kop, R. (2011). The Challenges to Connectivist Learning on Open Online Networks: Learning Experiences during a Massive Open Online Course. The International Review Of Research In Open And Distributed Learning, 12(3), 19. https://doi.org/10.19173/irrodl.v12i3.882

Koufaris, M., Kambil, A., \& LaBarbera, P.A. (2002). Consumer Behavior in Web-Based Commerce: An Empirical Study. International Journal of Electronic Commerce, 6(2), 115138. doi:10.1080/10864415.2001.11044233

Lee, D., Watson, S. L., \& Watson, W. R. (2019). Systematic literature review on selfregulated learning in massive open online courses. Australasian Journal of Educational Technology, 35(1), 28-41. doi: 10.14742/ajet.3749

Lei, S. A. (2010). Intrinsic and extrinsic motivation: evaluating benefits and drawbacks from college instructors' perspectives. Journal of Instructional Psychology, 37(2), 153-160.

Letcher, D. W., \& Neves, J. S. (2010). Determinants of undergraduate business student satisfaction. Research in Higher Education Journal, 6, 1-26. doi:10.1108/09513540510582426

Li, K., \& Moore, D. R. (2018). Motivating students in massive open online courses (MOOCs) using the attention, relevance, confidence, satisfaction (arcs) model. Journal of Formative Design in Learning, 2(2), 102-113.

Liu, S.H., Liao, H.L., \& Pratt, J.A. (2009). Impact of media richness and flow on e-learning technology acceptance. Computers \& Education, 52(3), 599-607.

doi:10.1016/j.compedu.2008.11.002

Liyanagunawardena, Tharindu R., Lundqvist, K., Mitchell, R., Warburton, S., y Williams, S. A. (2019). A MOOC Taxonomy Based on Classification Schemes of MOOCs. European Journal of Open, Distance and E-Learning, 22(1), 85-103. Retrieved from http://www.eurodl.org/?p=current\&sp=full\&article $=798$ 
Lorenzo, G., Oblinger, D., \& Dziuban, C. (2007). How choice, co-creation, and culture are changing what it means to be net savvy. Educause Quarterly, 30(1), 6-12. Retrieved from https://www.learntechlib.org/p/101304/

Martin, N., Kelly, N., \& Terry, P. C. (2018). A framework for self-determination in massive open online courses: Design for autonomy, competence, and relatedness. Australasian Journal of Educational Technology, 34(2), 35-55. doi: 10.14742/ajet.3722

Melone, N. (1990). A theoretical assessment of the user-satisfaction construct in information systems research. Management Science, 36(1): 76-91. Retrieved from https://www.jstor.org/stable/2632096

Milligan, C., \& Littlejohn, A. (2017). Why study on a MOOC? The motives of students and professionals. International Review of Research in Open and Distance Learning, 18(2), 93102. doi:10.19173/irrodl.v18i2.3033

MOOCs@Edinburgh Group. (2013).MOOCs@Edinburgh Re-port \#1. Retrieved from https://www.era.lib.ed.ac.uk/bitstream/handle/1842/6683/Edinburgh_MOOCs_Report2013_n o1.pdf

Nawaz, H., Amin, M. A., \& Tatla, I. A. (2015). Factors affecting students' motivation level to learn English as a second language in the Pakistani university context. Journal of Research \& Reflections in Education, 2, 103-115. Retrieved from http://ue.edu.pk/jrre/articles/92002.pdf

Nikou, S. A., \& Economides, A. A. (2017). Mobile-based assessment: Integrating acceptance and motivational factors into a combined model of self-determination theory and technology acceptance. Computers in Human Behavior, 68, 83-95. doi:10.1016/j.chb.2016.11.020

Núñez Alonso, J. L., Martín-Albo Lucas, J., \& Navarro Izquierdo, J. G. (2005). Validación de la versión española de la Échelle de Motivation en Éducation. Psicothema, 17(2), 344-349.

Retrieved from http://www.psicothema.com/psicothema.asp?id=3110

Panopoulos, A. P., \& Sarri, K. (2013). E-mentoring: The adoption process and innovation challenge. International Journal of Information Management, 33(1), 217-226.

doi:10.1016/j.ijinfomgt.2012.10.003

Perin, M. G., Sampaio, C. H., Simões, C., \& de Pólvora, R. P. (2012). Modeling antecedents of student loyalty in higher education. Journal of Marketing for Higher Education, 22(1), 101-116. doi:10.1080/08841241.2012.705797

Pituch, K.A., \& Lee, Y.-K. (2006). The influence of system characteristics on e-learning use. Computers \& Education, 47, 222-244. doi:10.1016/j.compedu.2004.10.007

Pozón-López, I., Kalinic, Z., Higueras-Castillo, E., \& Liébana-Cabanillas, F. (2019). A multianalytical approach to modeling of customer satisfaction and intention to use in Massive Open Online Courses (MOOC). Interactive Learning Environments, 1-19. doi:10.1080/10494820.2019.1636074

Reichheld, F. F. (2003). The one number you need to grow. Harvard Business Review, 81(12), 46-54. Retrieved from https://hbr.org/2003/12/the-one-number-you-need-to-grow

Riel, J., \& Lawless, K. A. (2017). Developments in MOOC technologies and participation since 2012: Changes since "The year of the MOOC". In M. Khosrow-Pour (Ed.), Encyclopedia of Information Science and Technology (4th Ed.), Hershey, PA: IGI Global. doi:10.4018/978-1-5225-2255-3.ch686 
This is an authors' version of the article published in "Interactive Learning Environments". The final authenticated version is available online at: $h$ ttp://dx.doi.org/10.1080/10494820.2020.1799020

Roca, J. C., Chiub, C. M., \& Martínez, F. J. (2006). Understanding e-learning continuance intention: An extension of the Technology Acceptance Model. International Journal HumanComputer Studies, 64, 683-696. doi:10.1016/j.ijhcs.2006.01.003

Ryan, R. M., \& Deci, E. L. (2000). Self-determination theory and the facilitation of intrinsic motivation, social development, and well-being. American Psychologist, 55(1), 68-78. Retrieved from https://www.ncbi.nlm.nih.gov/pubmed/11392867

Sánchez-Franco, M.J. (2010). WebCT-the quasimoderating effect of perceived affective quality on an extending technology acceptance model. Computers \& Education, 54(1), 37-46. doi:10.1016/j.compedu.2009.07.005

Sarstedt, M., \& Wilczynski, P. (2009). More for less? A comparison of single-item and multiitem measures. Die Betriebswirtschaft, 69(2), 211.

Schmidt, G. (2014). Personal growth as a strong element in the motivation of Australian university students to learn German. Australian Review of Applied Linguistics, 37, 145-160. Retrieved from https://search.informit.com.au/documentSummary; $d n=765247312743220 ;$ res=IELAPA

Shu-Sheng, L., \& Hsiu-Mei, H. (2011). Exploring Learners' Acceptance Toward Mobile Learning. In T. Teo (Ed.), Technology Acceptance in Education (pp. 145-157). Rotterdam: Sense Publishers. doi: 10.1007/978-94-6091-487-4_8

Siemens, G. (2005). Connectivism: A learning theory for the digital age. International Journal of Instructional Technology and Distance Learning, 2(1), 3-10.

Szymanski, D. M., \& Hise, R. T. (2000). e-Satisfaction: An Initial Examination. Journal of Retailing, 76(3), 309-322. doi:10.1016/S0022-4359(00)00035-X

Terras, M. M., \& Ramsay, J. (2015). Massive open online courses (MOOCs): Insights and challenges from a psychological perspective. British Journal of Educational Technology, 46(3), 472-487. doi:10.1111/bjet.12274

Tsai, Y. H., Lin, C. H., Hong, J. C., \& Tai, K. H. (2018). The effects of metacognition on online learning interest and continuance to learn with MOOCs. Computers \& Education, 121, 18-29.

Tu, C.-H., \& McIsaac, M. (2002). The relationship of social presence and interaction in online classes. The American Journal of Distance Education, 16(3), 131-150. doi:10.1207/S15389286AJDE1603_2

Uçar, H., \& Kumtepe, A. T. (2018). Integrating motivational strategies into massive open online courses (MOOCs): The application and administration of the motivation design model. In Administrative Leadership in Open and Distance Learning Programs (pp. 213-235). IGI Global.

Vallerand, R.J., Pelletier, L-G., Blais, M.R., Briere, N.M., Senecal, C., \& Vallieres, E.F. (1992). The Academic Motivation Scale: A Measure of Intrinsic, Extrinsic, and Amotivation in Education. Educational and Psychological Measurement, 52, 1003-1007. doi:10.1177/0013164492052004025

Venkatesh, V., Morris, M. G., Davis, G. B., \& Davis, F. D. (2003). User acceptance of information technology: Toward a unified view. MIS Quarterly, 27(3), 425-478. Retrieved from https://www.jstor.org/stable/30036540 
Wang, Y., \& Baker, R. (2015). Content or platform: Why do students complete MOOCs? Journal of Online Learning and Teaching, 11(1), 17-30. Retrieved from http://jolt.merlot.org/voll1no1/Wang_0315.pdf

Wanous, J. P., Reichers, A. E., \& Hudy, M. J. (1997). Overall job satisfaction: How good are single-item measures? Journal of Applied Psychology, 82(2), 247-252. Retrieved from https://www.ncbi.nlm.nih.gov/pubmed/9109282

Watted, A., \& Barak, M. (2018). Motivating factors of MOOC completers: Comparing between university-affiliated students and general participants. The Internet and Higher Education, 37, 11-20. doi:10.1016/j.iheduc.2017.12.001

Wixom, B. H., \& Todd, P. A. (2005). A theoretical integration of user satisfaction and technology acceptance. Information Systems Research, 16(1), 85-102.

doi:10.1287/isre. 1050.0042

Wu, B., \& Chen, X. (2017). Continuance intention to use MOOCs: Integrating the technology acceptance model (TAM) and task technology fit (TTF) model. Computers in Human Behavior, 67, 221-232. doi:10.1016/j.chb.2016.10.028

Xiong, Y., Li, H., Kornhaber, M. L., Suen, H. K., Pursel, B., \& Goins, D. D. (2015). Examining the relations among student motivation, engagement, and retention in a MOOC: A structural equation modeling approach. Global Education Review, 2(3). 23-33. Retrieved from https://eric.ed.gov/?id=EJ1074099

Yang, Q. (2014). Students' motivation in asynchronous online discussions with MOOC mode. American Journal of Educational Research, 2(5), 325-330. Retrieved from http://pubs.sciepub.com/education/2/5/13/index.html

Yuan, L., \& Powell, S. (2013). MOOCs and open education: Implications for higher education. Bolton: CETIS. Retrieved from http://publications.cetis.ac.uk/2013/667

Zeithaml, V.A., Berry, L.L., \& Parasuraman, S. (1996). The behavioral of service quality. Journal of Marketing, 60(2), 31-46. Retrieved from https://www.jstor.org/stable/1251929

Zheng, S., Rosson, M. B., Shih, P. C., \& Carroll, J. M. (2015). Understanding student motivation, behaviors and perceptions in MOOCs. In Proceedings of the 18th ACM Conference on Computer Supported Cooperative Work \& Social Computing (pp. 1882-1895). ACM. doi:10.1145/2675133.2675217

\section{Appendix}

Items, scales and psychometric properties of the scales

\begin{tabular}{|c|c|c|c|}
\hline Constructs & $\begin{array}{c}\text { Standardized } \\
\text { loadings }\end{array}$ & $\mathbf{C R}$ & AVE \\
\hline \multicolumn{4}{|l|}{ Perceived Usefulness (0: Totally disagree; 10: Totally agree) } \\
\hline PU01: In general I think that the Abierta-UGR course format is useful. & $.50 * * *$ & \multirow[t]{4}{*}{.83} & \multirow[t]{4}{*}{.58} \\
\hline $\begin{array}{l}\text { PU02: Using the Abierta-UGR course format makes the course more interesting } \\
\text { than doing it face-to-face }\end{array}$ & $.60 * * *$ & & \\
\hline $\begin{array}{l}\text { PU03: Using the Abierta-UGR course format improves the effectiveness of my } \\
\text { learning. }\end{array}$ & $.93 * * *$ & & \\
\hline PU04: The Abierta-UGR course format improves my learning performance. & $.92 * * *$ & & \\
\hline
\end{tabular}


This is an authors' version of the article published in "Interactive Learning Environments". The final authenticated version is available online at: $h$ ttp://dx.doi.org/10.1080/10494820.2020.1799020

\begin{tabular}{|c|c|c|c|}
\hline $\begin{array}{l}\text { PEU01: The way of interacting in the Abierta-UGR course format is fair and easy to } \\
\text { understand }\end{array}$ & $.70 * * *$ & \multirow[t]{3}{*}{.81} & \multirow[t]{3}{*}{.59} \\
\hline PEU02: I find that the Abierta-UGR course format is easy to follow. & $.77 * * *$ & & \\
\hline $\begin{array}{l}\text { PEU03: I find that the Abierta-UGR course format allows me to easily do what I } \\
\text { need to do in the course. }\end{array}$ & $.82 * * *$ & & \\
\hline \multicolumn{4}{|l|}{ Attitude Towards Using (0: Totally disagree; 10: Totally agree) } \\
\hline ATU01: After using the Abierta-UGR course format, I think that it is comfy. & $.83 * * *$ & \multirow[t]{3}{*}{.76} & \multirow[t]{3}{*}{.52} \\
\hline $\begin{array}{l}\text { ATU02: After using the Abierta-UGR course format, I think that I saved time in } \\
\text { relation to the face-to-face option. }\end{array}$ & $.56 * * *$ & & \\
\hline ATU03 After using the Abierta-UGR course format, I think that it was safe. & $.74 * * *$ & & \\
\hline \multicolumn{4}{|l|}{ EM External regulation (0: Totally disagree; 10: Totally agree) } \\
\hline M01: I did the course to obtain credits & $1.00 * * *$ & -- & -- \\
\hline \multicolumn{4}{|l|}{ Im-to-Know (0: Totally disagree; 10: Totally agree) } \\
\hline $\begin{array}{l}\text { M02: I did the course because this type of course allows me to improve my } \\
\text { knowledge in subjects that I like }\end{array}$ & $.82 * * *$ & \multirow[t]{2}{*}{.75} & \multirow[t]{2}{*}{.59} \\
\hline $\begin{array}{l}\text { M03: I did the course because this type of course allows me to discover new things } \\
\text { unknown to me }\end{array}$ & $.72 * * *$ & & \\
\hline \multicolumn{4}{|l|}{ Loyalty (0: Totally disagree; 10: Totally agree) } \\
\hline \multicolumn{4}{|l|}{ Now that I have completed this Abierta-UGR course... } \\
\hline Loyal01: I will tell others about its positive aspects & $.86 * * *$ & \multirow[t]{4}{*}{.90} & \multirow[t]{4}{*}{.70} \\
\hline Loyal02: I will recommend it to anyone who asks me for advice & $.90 * * *$ & & \\
\hline Loyal03: I will encourage my classmates to take courses that this platform & $.88 * * *$ & & \\
\hline Loyal04: I will take other courses that use this platform & $.71 * * *$ & & \\
\hline \multicolumn{4}{|l|}{ Satisfaction } \\
\hline \multicolumn{4}{|l|}{ In general, my experience of the audiovisual contents on the Abierta-UGR platform... } \\
\hline Sat01: leaves me feeling (0) totally dissatisfied - (10) totally satisfied) & $.83 * * *$ & \multirow[t]{5}{*}{.92} & \multirow[t]{5}{*}{.74} \\
\hline Sat02: is that they are $(0)$ Not interesting at all - (10) very interesting) & $.84 * * *$ & & \\
\hline \multicolumn{2}{|l|}{ In general, my experience of the Abierta-UGR course format leaves me feeling... } & & \\
\hline Sat03: (0) totally dissatisfied (10) totally satisfied) & $.90 * * *$ & & \\
\hline Sat04: (0) very unhappy (10) very happy) & $.87 * * *$ & & \\
\hline
\end{tabular}

Note: All items have been translated from the original Spanish instrument.

$* * * p<0.01$ 